\title{
Training of alphanumeric filing system and electronic filing to teachers and administrative staffs of junior high school in Dolok Ilir
}

\author{
Aryanti Sariartha Sianipar ${ }^{1 *}$, Amlys Syahputra Silalahi ${ }^{1}$, Tetty Yuliaty ${ }^{1}$, Doli Muhammad \\ Ja'Far Dalimunthe $^{1}$, Yan Batara Putra Siringoringo ${ }^{2}$ \\ ${ }^{1}$ Faculty of Economics and Business Universitas Sumatera Utara \\ ${ }^{2}$ Faculty of Mathematics and Natural Sciences Universitas Sumatera Utara \\ *Email: aryantisariartha@usu.ac.id
}

\begin{abstract}
The archiving process uses a certain system in the preparation, maintenance of records so that they can be recovered quickly and precisely and easily for destruction of archives based on certain criteria. The archive itself has enormous benefits for educational organizations, because the archive is information on activities carried out by schools. Archives in schools need to be well managed, so that archives can be used effectively and efficiently and have good accessibility. The arrangement of archives usually has several problems including, documents cannot be recovered because they are lost, the number of documents is always increasing every day, the storage area for documents is too small compared to the number of documents, so the space is insufficient, not to mention the lack of staff capacity, and the system. The storage is not in accordance with the principles of archiving. For this reason, this service is aimed at providing knowledge and skills in arranging archives in accordance with RI archiving principles, namely using an alphanumeric archive storage system, through training followed by practice and evaluation. Adequate archive facilities and infrastructure are needed in schools for this training. After the dedication was carried out, teachers and administrative staff experienced an increase in knowledge and skills in compiling personal archives and schools got the facilities and infrastructure that supported archiving. Furthermore, an evaluation of the application of archiving in schools is carried out in order to determine its effectiveness in school management.
\end{abstract}

Keyword: Administrative; Archive; Alphanumeric; School; Teachers

\section{INTRODUCTION}

This community service is based on various reasons for wanting to provide new skills to administrative staff at schools in the arrangement of archive storage which currently does not meet standards. Archive itself is an archive management process of monitoring, storing, and securing documents both in paper and electronic media (Odgers 2005). Archiving is also the process of managing or organizing archives by using a certain system so that archives can be found easily and quickly when needed (Drs. I.G. Wursanto, 1989). Archiving as a process that focuses on the efficiency of office administration, managing and destroying documents when not needed (Charman, 1998). So archiving is a very important thing for administrative staff to understand at PTPN IV Dolok Ilir Private Junior High School so that archives managed by PTPN IV Dolok Ilir Private Junior High School can really provide good performance. Partners in this community service program are junior high schools in Serbalawan. The need for archives to be managed properly and carefully as well as better service is a necessity that cannot be avoided today. Education is the level of government that is closest to society, therefore the function of archives for every education is very important, as a provision for making considerations and decisions. According to Moekijat, the problems in storing archives that are often encountered in archival administration:

- The use of a classification system that is wrong

- Poor organization and unclear definition of responsibilities and powers

- Untrained employees

In archival storage there are steps or archive storage procedures according to (Amsyah, 2008: 5) which are as follows: 
1. Archive inspection procedures for storing archives are the preparatory steps for storing archives by examining each archive sheet to obtain certainty. Whereas the archives are ready for storage, the clarity of the letter must be requested first to the rightful person and also if it happens that the letter which has not been marked has been saved. So in this case it can be said that the archive is declared lost.

2. Indexing Archives this is the procedure for storing records by indexing. Indexing is a job that determines on any name or subject, other catch words will be stored. In the alphabetical system the catch word is the name of the sender, namely the name of the body on the head of the letter for the type of incoming letter and also the name of the individual for the type of outgoing letter. Thus, incoming and outgoing mail will be stored in one folder with the same catch word.

3. Giving Signs. This step is also commonly called coding, done simply by marking a line or circle with a striking color on the complete word that has been determined in the indexing step. With this sign, the letter will be sorted and stored, in addition, if one day this letter is borrowed or files out, the officer will easily save the letter based on the existing storage sign (code).

So the use of the correct system in archiving is very important, employees who have the ability are an absolute requirement for managing school administration. Therefore, their ability to manage archives must be equipped with competence in this field of expertise so that an understanding of archives can be the basis for decision making and excellent service, of course with various forms of archive storage that have been set according to standards.

Therefore, it is time for elementary school to pay attention to the management of its archives in order to maintain the integrity and security of the information created so that it will facilitate finding the archives when needed and the process of consideration and decision making. The importance of good archive governance can also affect the quality of education services to students and other stakeholders. Empowerment of duties and functions of archives in junior high schools must be further enhanced roles and capacities.

Archives are created along with the activities of institutions. The bigger the institution, the more archives that are created. The problems associated with recovering the required archives are of course increasingly complex, requiring proper archive management. Archival management problems can be found in junior high schools which have the responsibility of providing services to students, communities, and other stakeholders whose requests do not recognize working time / hours. The objectives of this activity are:

1. Fostering motivation and increasing awareness of SMP to be able to manage records properly and correctly;

2. Equip the abilities and skills of academic staff to manage archives as an effort to improve service and retrieval;

3. To equip junior high school's abilities and skills in carrying out service assignments to students and other stakeholders. Thus gradually and continuously the ability of SMP in managing archives will increase gradually, as well as the provision of services to the community, the better it will be to realize an excellent service.

The benefits expected from this activity for the targeted school are:

1. Improve the abilities and skills of employees in junior high schools in managing good records according to the standards of having knowledge of the importance of archives for the continuity of education from time to time;

2. Have an awareness of the importance of managing archives in junior high schools properly and correctly in order to solve educational problems and academic activities.

3. Can manage records properly and correctly and use them as an effort to improve service. 


\section{METHODS}

\subsection{Problems of the Targeted Institution}

According to a conversation between the targeted school and community service team, the problems that need to be solved are as follows:

a. Aspects of human resources, the competence of human resources is low, both administrative staff in junior high schools, who have not mastered a standard filing system so that the work process is hampered.

b. Financial Aspects, existing condition is a limited funds owned by the school, as a result, many employees cannot attend training or keep up with developments or improvements in employee competencies.

c. Facilities Aspect, low standard facilities and lack of adequate filing equipment, this situation makes it difficult for employees to implement a standardized filing system.

Justification of proposers with partners in determining the agreed priority issues to be resolved during the implementation of the mono year program. Justification of the priority problems is to carry out training activities planned for September 10, 2020. After conducting a situation analysis and conducting in-depth interviews and observations at school on the date. Thus the Proposing Team can conclude several things that are priority issues in this PKM activity, namely:

a. Improving HR Competence by training on alphanumeric system archiving

b. The application of the alphanumeric archiving system and the application of electronic filing

c. Procurement of archive practice tools, to complement archival letters that have not yet been printed respectively

d. Reporting on the results of activities and their implementation

\subsection{Methods}

Programs that have been negogiatedbetween two parties to solve the two main aspects within the period of community service is by increasing HR competencies such as training for archiving systems for the alphanumeric system, the method of implementing community service programs is carried out in the form of training with these steps:

a. Theory Presentation

The theory presentation is used to convey in two directions by explaining to participants about the material related to the theory and concept of archive management. The material presented was the procedure for storing archives based on an alphanumeric system in accordance with archiving rules using a classification pattern according to ANRI standards.

b. Practice

In this training, learning is carried out by practicing in a direct administrative work environment how the alphanumeric archive storage system is carried out to implement the theories that have been obtained so that the theoretical information obtained can be practiced directly. Practice manual family file management. First, participants are asked to fill out the archive form sheet provided by the PKM members. And hand out a few skates of archive storage. Meanwhile, during the electronic filing practice, the participants can immediately practice using existing archiving equipment and tools.

c. Independent task

To increase the skills and abilities of participants, they are given assignments using letters in the school office, so that they can be immediately understood in their application

d. Evaluation

Evaluation is carried out during the training process. Evaluation during the practical process will make it easier for assistants (lecturers) to provide assistance so that participants can manage archives properly. Process evaluation is carried out so that participants can immediately identify the difficulties experienced by the participants. 


\subsubsection{Assistance}

Assistance during the activity was carried out to find out and help with difficulties experienced by participants. Post training assistance is intended to provide direction and guide archive management for participants after training. The Proposer Team receives questions and consultations related to problems that occur in the implementation of theory and practice through telephone and short messages. So the approach method is carried out with several phases to make sure the application of the alphanurmeric archiving system and the application of electronic filing as follows:

a. Monitoring the participants, participants who have completed the training will be monitored by the Proposing Team according to the agreed time, whether they have implemented what was trained

b. Transfer of Science and Technology This training will also use several electronic equipment in organizing archives such as making agenda books and printing incoming letters and others.

c. Report on the results of activities The results of this activity will be made into a report to be used as material for evaluation and improvement of things that need to be done

d. Work procedures

- Work procedures to be carried out in the implementation of community service

- Evaluating and discussing the archiving learning process that has been carried out by administrative staff at SMP.

- Evaluating and discussing the application of archiving systems in the daily arrangement of archives in the school administration office so far

- Conduct socialization of meetings to conduct hands-on practice-based training

- Determine the training time based on mutual agreement

- Collect files from administrative staff at the school office

- Provide training modules

- Providing practice-based Alphanumeric Archiving Training

- Giving Independent Assignments

- Evaluates, checks and corrects existing errors

- Mentoring can be done during training activities or after training

- Monitoring the application of archives by administrative staff

\subsubsection{Partner's Role}

The targeted school should also work son several activities to succeed the training in terms of:

a. Readiness inp providing a place and time for the implementation of training activities

b. Readiness to provide human resources who will be given training

c. Readiness to provide time to be interviewed and discuss the problems at hand.

d. Agreed if a photo needs to be taken on the administrative staff workplace at the school

e. Give permission to record and document the activities required for partner documents

f. Willing to apply the filing system that has been studied

g. Be pleased to attend socialization, archiving training according to standards or according to archiving rules

h. Willing to attend electronic archiving training and apply it.

i. Ageed to work together with the community service proposer team to determine the technical implementation of activities for the smooth and successful implementation of activities

\section{RESULT AND DISCUSSION}

The alphanumeric system archiving training activity according to the archival principles of the Republic of Indonesia was held on September 10, 2020 starting at 10.00 AM to 05.00 PM. This training was attended by 12 participants consisting of teachers and administration of PTPN IV Dolok 
Ilir Private Junior High School. The number of participants who attended was reached $100 \%$ of the targeted number.

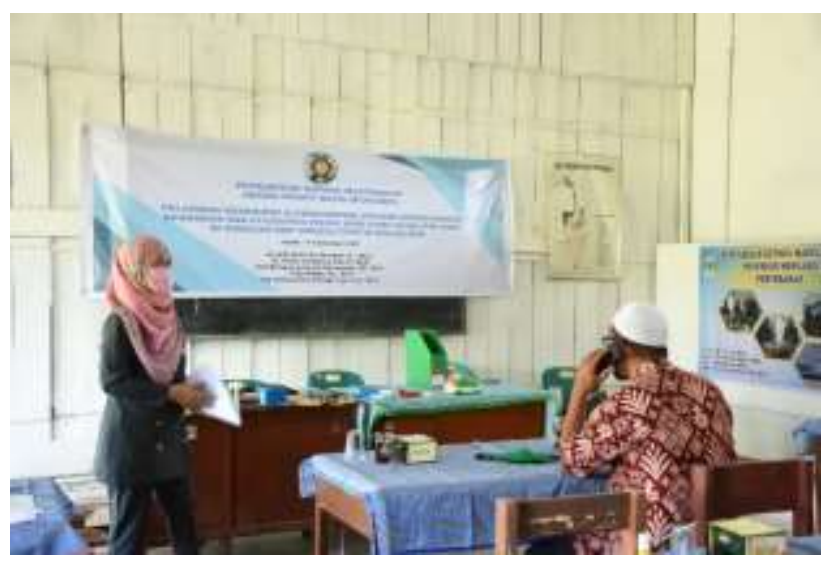

Picture 3.1. The theory was delivered by the notespeaker

The training consists of theory presentation, practice, independent assignment and evaluation. The theory was presented by the notespeaker, Dr. Tetty Juliaty, S.E., M.Si. Meanwhile, the practice was delivered by notespeaker and accompanied by a team of Aryanti Sariartha Sianipar, SE, M.Sc, Dr. Amlys Syahputra Silalahi, M.Si., Doli Dalimunthe, SE, M.Si., and Yan Batara Putra Siringoringo, S .Si., M.Si. Based on the results of the pretest carried out, it can reveal that the knowledge of the participants, both teachers and administrative staff, is still very limited. Therefore this training is more helpful in increasing knowledge and retraining. This training is also a refreshing because it teaches how to store archives correctly and according to RI archival principles. With an alphanumeric archive storage system with a classification pattern.

Then with the delivery of the material, here are questions and answers and discussion for certain matters and it is followed up with practice, all of which practical material is provided by the community service team. Furthermore, the theory is evaluated and to make sure there exists an increasing skills of the participants, all participants are given independent assignments and if they still want to discuss, time is provided for guidance in making independent tasks. After all participants are expected to be able to practice it at school and provide assistance to those who still need it. Better understanding of archiving before training begins (pre-test) and after training (post-test). The results after training and provided guidance and assistance:

- Increase the knowledge and skills of the participants in the correct arrangement of archives and according to the rules of the Indonesian government and also the Indonesian laws and regulations regarding electronic archiving and archiving.

- Participants can find files in a relatively short time because they already understand the proper storage system.

- Participants can practice how to keep records that are correct and precise and in accordance with RI archiving rules. 


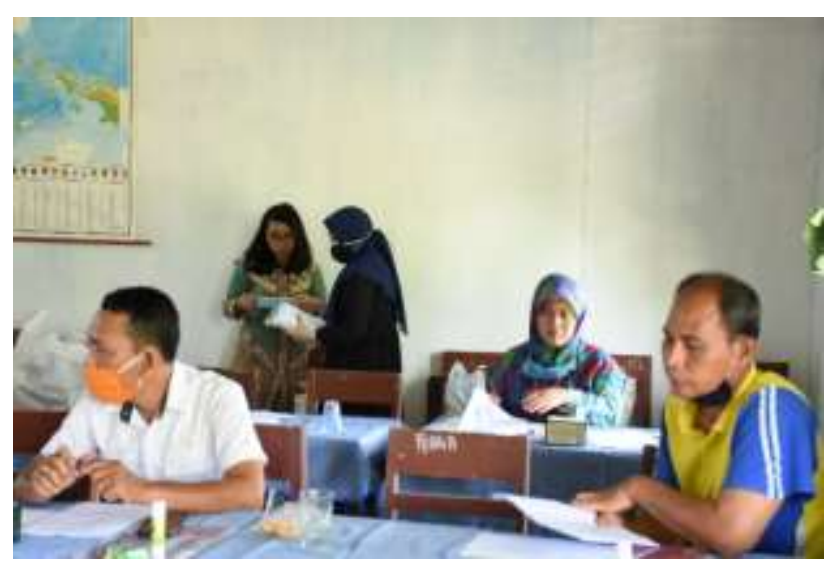

Picture 3.2 The participants listened to the theory presentation

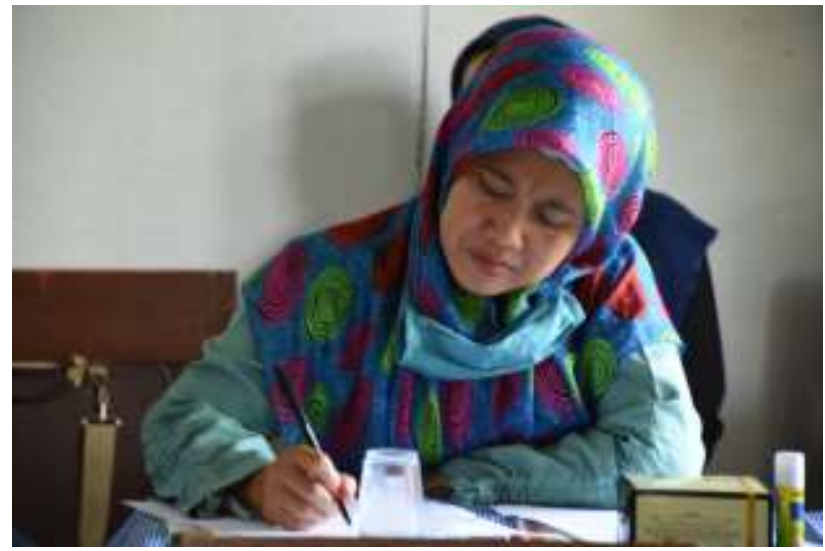

Picture 3.3. The participant practiced the alphanumeric filing system

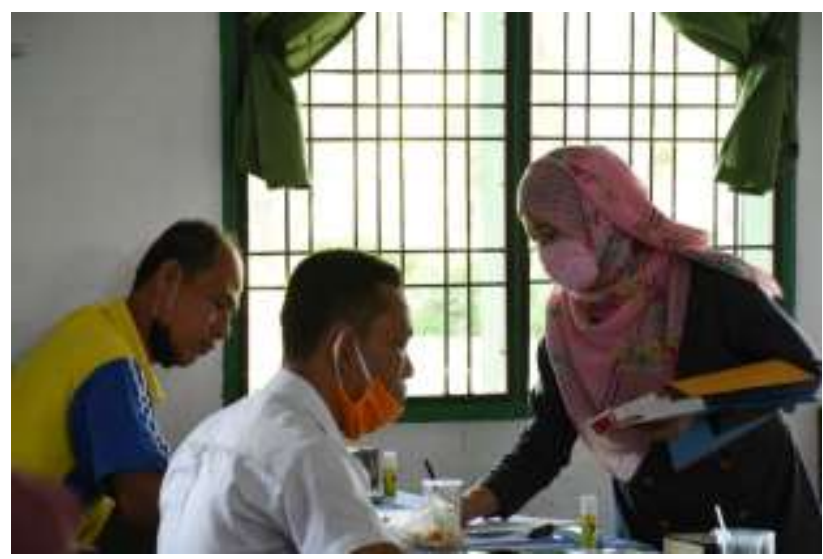

Picture 3.4. The team performed an assitance to the participants

Based on the results of the analysis between the partners and the PkM team, several things that become priority problems in this PKM activity are:

a. Improving HR Competence by training on alphanumeric system archiving

b. Alphanurmeric Archiving Application System and Electronic Archiving Application

c. Procurement of archive practice tools, to complement archival letters that have not yet been printed respectively 
Based on the method of describing theory, practice, independent assignments, and evaluation of the results achieved, among others:

a. Human resource competency is increased with new expertise regarding archiving. Arrange and store files with an alphanumeric system to make it more neat and structured.

b. Teachers and administrative staff can store files in filing cabinets according to the order of importance, for example by incoming mail, outgoing mail, alphabetically, region and so on.

c. The private junior high school PTPN IV Dolok Ilir is equipped with tools for practicing the alphanumeric system such as stationery, Glue Sticks, Orange paper, paper clips, perforators, post it notes, staplers and staples, guides / tabs, trigonal clip dispositions, agenda book formats, incoming and outgoing mail.

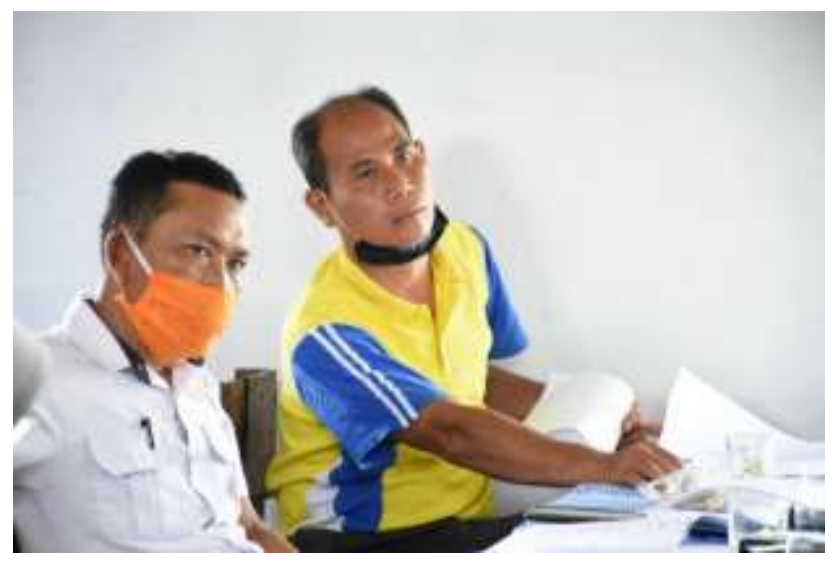

Picture 3.5. Participants finished the independent task

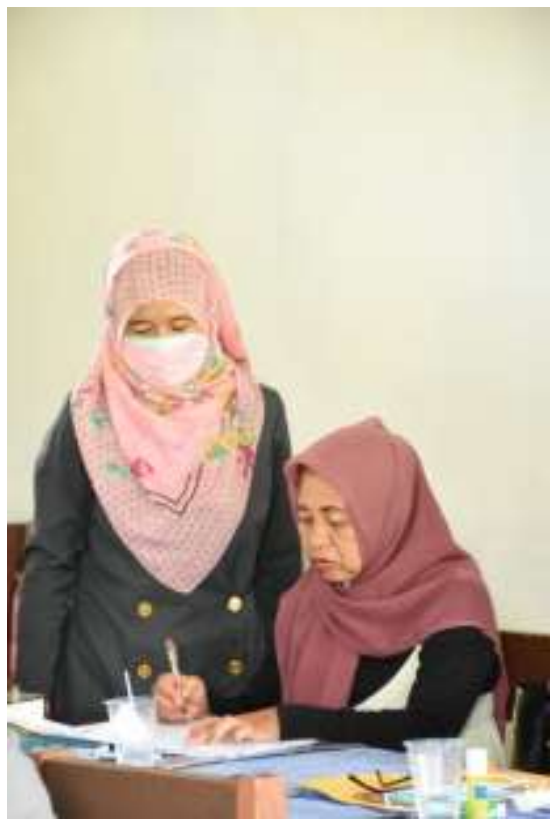

Picture 3.6. Participant's work was evaluated 


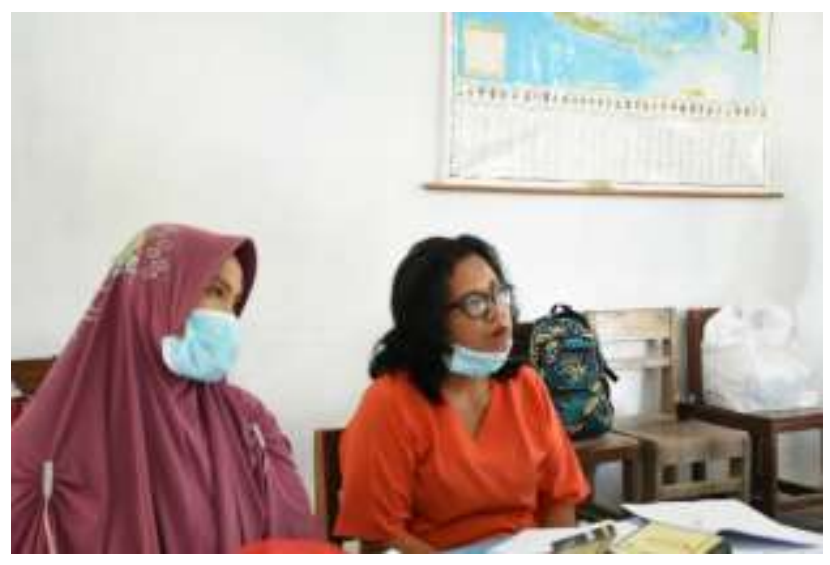

Picture 3.7. Particpants work was evaluated

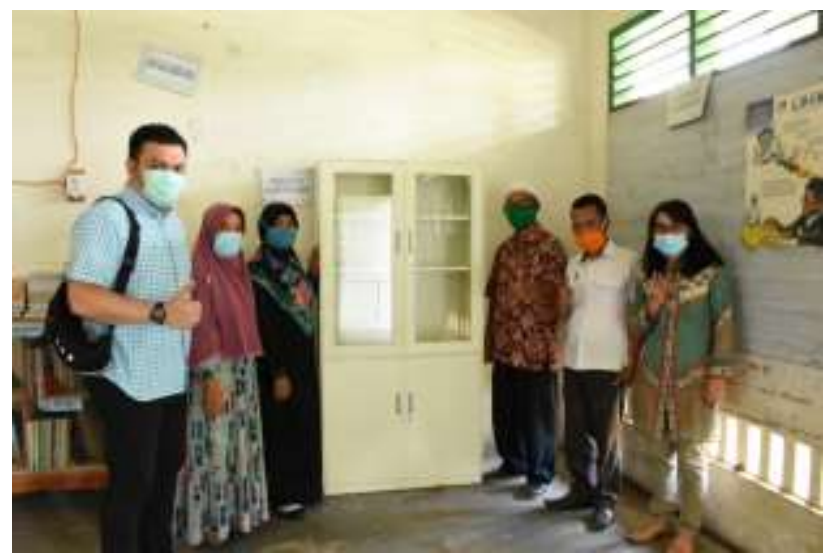

Picture 3.8. Tools and facilities of filing system were improved

Based on the implementation of the theoretical presentation, the teachers and administrative staff at Dolok Ilir Private Junior High School have a level of awareness and knowledge about archiving with the alpha numeric system.

\section{CONCLUSION}

According to the training of alphanumeric system to teachers and administrative staffs of the targeted junior high school, we derive several conculsions as follows: alphanumeric archive storage that conforms to RI principles is very helpful for schools and companies in keeping records that are correct and precise. Socialization of alphanumeric archive storage systems is still low.According to pretest the majority of participants do not know and understand the alphanumeric archive storage system that is in accordance with the principles of readiness and has now been established by the government. Arrangement of archives in schools is still in disarray due to the lack of skills of human resources in the archive sector. Our observations found the inadequate archive facilities and infrastructure at schools. On the other hand, administrative staff is less concerned with the arrangement of archives because they do not know about the correct and proper arrangement of archives. Archiving training and mentoring provide an increase in the ability of participants to organize correct and accurate records, according to RI principles. The principal has realized the importance of providing facilities and infrastructure in managing proper archives.

Thus community services suggested some of these ideas suc as provide training to staff and teachers who have not attended archiving training in accordance with the archiving rules of the Indonesian 
government. Provide more frequent guidance to administrative staff so that they are willing to organize school files properly. Moreover, support from school principals and institutions to provide archiving facilities and infrastructure so that they can be implemented in schools immediately

\section{ACKNOWLEDGMENTS}

This community service is funded and sponsored by Universitas Sumatera Utara through Lembaga Pengabdian kepada Masyarakat (LPPM) according to acontract named: Surat Perjanjian Penugasan Pelaksanaan Pengabdian Kepada Masyarakat Skim Dosen Mengabdi Sumber Dana Non PNBP USU T.A. 2020 Number: 666/UN5.2.3.2.1/PPM/2020 dated July 24th 2020.

\section{REFERENCES}

Amsyah, Z. (2015). Manajemen Sistem Informasi. Jakarta: Gramedia Pustaka Utama.

Odgers. P. (2005). Administrative Office Management Edisi Ketigabelas. New York: Thomson.

Peraturan pemerintah Republik Indonesia nomor 28 tahun 2012. Jakarta: ANRI

Sedarmayanti. (2008). Manajemen Sumber Daya Manusia. Jakarta: Grasindo.

Sugiarto, A., \& Wahyono, T. (2005). Manajemen Kearsipan Modern. Yogyakarta: Gava Media. 